\title{
Distribution of impurity elements in slag- silicon equilibria for oxidative refining of metallurgical silicon for solar cell applications
}

\author{
M. D. Johnston and M. Barati \\ Version Post-print/Accepted Manuscript \\ Citation Johnston, M.D. and Barati, M., 2010. Distribution of impurity elements \\ (published version) in slag-silicon equilibria for oxidative refining of metallurgical silicon \\ for solar cell applications. Solar energy materials and solar cells, 94(12), \\ pp.2085-2090. DOI: 10.1016/j.solmat.2010.06.025 \\ Copyright/License \\ (c) (7) $($ This work is licensed under the Creative Commons \\ International License. To view a copy of this license, visit \\ http://creativecommons.org/licenses/by-nc-nd/4.0/.
}

How to cite TSpace items

Always cite the published version, so the author(s) will receive recognition through services that track citation counts, e.g. Scopus. If you need to cite the page number of the author manuscript from TSpace because you cannot access the published version, then cite the TSpace version in addition to the published version using the permanent URI (handle) found on the record page.

This article was made openly accessible by $U$ of $T$ Faculty. Please tell us how this access benefits you. Your story matters. 


\title{
Distribution of Impurity Elements in Slag-Silicon Equilibria for Oxidative Refining of Metallurgical Silicon for Solar Cell Applications
}

\author{
M.D. Johnston ${ }^{\mathrm{a}^{*}}$ and M. Barati ${ }^{\mathrm{a}}$ \\ ${ }^{a}$ Department of Materials Science and Engineering, The University of Toronto, 184 College \\ Street, Toronto, ON, Canada, M5S3E4
}

\begin{abstract}
The possibility of refining metallurgical grade silicon to a high-purity product for solar cell applications by the slagging of impurity elements was investigated. Distribution coefficients were determined for $\mathrm{B}, \mathrm{Ca}, \mathrm{Mg}, \mathrm{Fe}, \mathrm{K}$ and $\mathrm{P}$ between magnesia or alumina saturated $\mathrm{Al}_{2} \mathrm{O}_{3}-\mathrm{CaO}$ $\mathrm{MgO}-\mathrm{SiO}_{2}$ and $\mathrm{Al}_{2} \mathrm{O}_{3}-\mathrm{BaO}-\mathrm{SiO}_{2}$ slags and silicon at $1500{ }^{\circ} \mathrm{C}$. The partitioning of the impurity elements between the molten silicon and slag was examined in terms of the basicity and oxygen potential of the slag, with particular focus on the behaviour of boron and phosphorus. The experimental results showed that both of these aspects of slag chemistry have a significant influence on the distribution coefficient of B and P. Increasing the oxygen potential by additions of silica was found to increase the distribution coefficients for both B and P. Increasing the basicity of the slag was not always effective in achieving high removal of these elements from the silicon as excess amounts of basic oxides lower the activity of silica and consequently the oxygen potential. The extent of this effect is such that increasing basicity can lead to a decrease in the distribution coefficient. Increasing lime in the slag increased distribution coefficients for $\mathrm{B}$ and $\mathrm{P}$, but this counterbalancing effect was such that distributions were lowest in the bariumcontaining slags, despite barium oxide being the most basic of the fluxes used in this study. The highest removal efficiencies achieved were of the order of $80 \%$ and $90 \%$ for B and $\mathrm{P}$ respectively. It was demonstrated that for the removal of B and $\mathrm{P}$ from metallurgical-grade silicon to solar-grade levels, a slag mass about 5 times the mass of silicon would be required.
\end{abstract}

Keywords: metallurgical silicon; impurity distribution; slag treatment; solar-grade silicon

\section{Introduction}

Several studies on energy generation and the environmental impact of solar-based power have shown that photovoltaic (PV) electricity is amongst the most environmentally benign sources of energy. A study [1] on the environmental impact of solar silicon presents very attractive figures for greenhouse gas emissions and energy payback time; $30 \mathrm{~g} / \mathrm{kWh}$ and 1.2 years, respectively. Another study [2] on $\mathrm{CO}_{2}$ emission of various electricity generation options estimates that solar electricity generates as low as $0.013 \mathrm{~kg} \mathrm{CO}_{2}-\mathrm{e} / \mathrm{kWh}$, about 80 times lower than that of coal-based electricity. However, today's cost of solar electricity being around $\$ 0.3$ $/ \mathrm{kWh}$, is about four times larger than the dominant nuclear and coal-based electricity [3]. This is partly because of the high cost and limited availability of silicon used in the manufacture of the PV cells. High-purity scrap silicon from the semiconductor industry $(99.9999999 \% \mathrm{Si})$ has

\footnotetext{
* Corresponding Author. Tel.: +1 4169785630

Email: murray.johnston@utoronto.ca
} 
mainly been used as the starting material for producing solar-grade silicon (SoG-Si) (99.9999\% $\mathrm{Si}$ ), which is ultimately used to fabricate a crystalline silicon PV cell.

The quest for developing a low-cost method of producing SoG-Si has been moving forward in the last decade to overcome the economic hurdle against widespread generation of PV electricity. Metallurgical-grade silicon (MG-Si) is a cheaper alternative to electronic scrap that can be produced on the large scale, but is of considerably lower purity (98-99\% Si).

Furthermore, it contains impurity elements that must be removed to low levels for the PV cell to operate at optimum efficiency. As such, MG-Si must still be refined by a cost-effective means for it to remain a possible starting material for the production of SoG-Si. Many techniques for refining MG-Si exist and must often be used in conjunction with one another to achieve the requisite purity for solar applications. Of all the impurities present in MG-Si, boron and phosphorus are often the most difficult to remove. This is because they are unresponsive to directional solidification, which is usually the final step in silicon refining. This is a major concern as these elements are typically doped to precise levels in photovoltaic silicon. It is the behaviour of these elements that will be the focus of this study.

Some impurity elements are easier to remove because of their low segregation coefficient between solid and liquid silicon. Studies have shown that using techniques such as the zone refining plasma-arc method [4], the impurities with a low segregation coefficient can be collected in a liquid portion of a sample then discarded. However, boron and phosphorus have relatively high segregation coefficients so are not readily removed by this method. One possible method of decreasing the segregation coefficient of these elements is to first alloy the silicon with a "getter" metal such as copper or iron [5], then solidify the liquid alloy to grow pure dendrites of Si. The getter metal, having a higher affinity for such impurities than silicon, increases absorption of these elements in the liquid phase; hence, a more pure Si crystal can form during solidification. However, the technique is not capable of achieving SoG-Si specifications in one stage, meaning further refining will still be required. Vacuum refining has been shown to be able to remove phosphorus, but long times and high power requirements make this technique unsuitable [6].

Another metallurgical refining technique for MG-Si involves melting it in the presence of a flux to produce a slag phase which can take up the impurity elements. For non-metallic impurities such as boron and phosphorus that will have acidic oxides, basic melts such as those based on alkali and alkali-earth oxides are expected to be the most appropriate to facilitate their extraction to a slag phase. Impurity elements are stabilised as an oxide in the slag with the inclusion of a suitable flux or gas to create oxidising conditions. Tanahashi et al, [7] proposed the treatment of $\mathrm{Si}$ with $\mathrm{CaO}$ based fluxes as one part of a more complex overall refining procedure. Other previous studies have focused on the use of highly basic fluxes containing $\mathrm{CaO}$ and $\mathrm{CaF}_{2}[8,9]$ but also make use of $\mathrm{SiO}_{2}$ to give the slag suitable oxidising potential. While this will reduce the basicity of the slag, saturating the slag with $\mathrm{SiO}_{2}$ may also prevent unacceptably high losses of silicon to the slag. Weiss and Schwerdtfeger [10] examined the behaviour of many elements in $\mathrm{CaO}-\mathrm{SiO}_{2}$ based ternary systems and showed that the removal of some metallic elements is also feasible by this method. However, it is reported [11] that the addition of excess $\mathrm{CaO}$ can increase the concentration of $\mathrm{Ca}$ in silicon, which, through ternary interactions, can in turn draw phosphorus back from the slag into the metal phase. Furthermore, boron, in group IIIA on the periodic table, is considered less acidic in nature and may not behave in exactly the same manner as phosphorus, in group VA. It is apparent, therefore, that the slag composition must be subject to fine control to optimise removal of both of these elements. 
Equilibrium studies between silicon and oxide phases have also been carried out to determine thermodynamic quantities for impurities in silicon. A review of the available thermodynamic data pertaining to impurities that are typically required to be removed from $\mathrm{Si}$ for PV applications was conducted by Morita and Miki [12].

Despite the expected complexity associated with optimising slag chemistry, comprehensive data on the behaviour of impurities in terms of fundamental variables such as temperature and slag composition are quite limited. In this work, the flux-refining of $\mathrm{MG}-\mathrm{Si}$ is examined in detail using $\mathrm{Al}_{2} \mathrm{O}_{3}-\mathrm{CaO}-\mathrm{MgO}-\mathrm{SiO}_{2}$ and $\mathrm{Al}_{2} \mathrm{O}_{3}-\mathrm{BaO}-\mathrm{SiO}_{2}$ slags. The slag composition was selectively varied with the intent of determining the effect of slag basicity and oxygen potential on the extraction of impurities from the silicon metal phase.

\section{Experimental}

\subsection{Materials}

To facilitate the analysis of impurities, a silicon master alloy was synthesized by doping one kilogram of milled metallurgical silicon with $3 \mathrm{~g}$ each of 95-97\% B (Sigma-Aldrich) and $>97 \%$ red $\mathrm{P}$ powders (Riedel-de Haem). This mixture was melted in two portions, approximately $500 \mathrm{~g}$ each, in magnesia crucibles under an argon atmosphere inside a muffle furnace at $1485{ }^{\circ} \mathrm{C}$ for 2.75 hours. Analysis of these master alloys is given in Table I.

Fluxes used in the preparation of the slags were first dried at $105^{\circ} \mathrm{C}$ for one hour then weighed and mixed thoroughly in the desired ratio for each particular experiment. Where basicity $(B)$ was to be varied in the $\mathrm{Al}_{2} \mathrm{O}_{3}-\mathrm{CaO}-\mathrm{MgO}-\mathrm{SiO}_{2}$ system, slags were prepared in the range $0.21<B<1.4$. Where basicity was held constant, slags were prepared with $B=1.08$. The effect of slag basicity was to be further investigated by varying the $\mathrm{BaO}: \mathrm{SiO}_{2}$ ratio of the $\mathrm{Al}_{2} \mathrm{O}_{3}-$ $\mathrm{BaO}-\mathrm{SiO}_{2}$ slag. Here, slags were prepared in the range $0.33<B<0.82$. For the purposes of this study, $(B)$ refers to the ratio, by weight, of $(\mathrm{CaO}+\mathrm{MgO}) /\left(\mathrm{SiO}_{2}+\mathrm{Al}_{2} \mathrm{O}_{3}\right)$, or, $(\mathrm{BaO}) /\left(\mathrm{SiO}_{2}+\mathrm{Al}_{2} \mathrm{O}_{3}\right)$. The composition ranges in all cases were designed to give a single molten slag phase at $1500{ }^{\circ} \mathrm{C}$.

\subsection{Methods}

Before melting, flux mixtures were pressed into a pellet. Typically, $5.5 \mathrm{~g}$ of doped $\mathrm{Si}$ and $7.5 \mathrm{~g}$ of fluxes were used in each experiment. The slag and alloy were brought into equilibrium in a magnesia or alumina crucible in an inert atmosphere inside a vertical tube furnace. The crucible was suspended inside the furnace by means of an alumina rod and pin that were attached to the top end cap. A schematic diagram of the furnace setup is shown in Fig. 1. The crucible was held in the cold zone of the furnace while it was flushed with argon for 30 minutes. After flushing, the crucible was slowly lowered to the hot zone before the temperature was increased to $1500{ }^{\circ} \mathrm{C}$. The temperature of the hot zone was measured using a B-type (Pt-6\% Rh/Pt-30\% Rh) thermocouple, held in place by the bottom end-cap at the level of the base of the crucible. Argon was passed through the furnace at a rate of approximately $300 \mathrm{~mL} / \mathrm{min}$ for the duration of the experiment.

At the end of each experiment, the crucible assembly was removed from the top of the furnace and quenched in a water bath. Quenching typically took several seconds. After being left to dry, the slag and metal phases were physically separated from the crucible, then ground to a powder for digestion and analysis. 
A series of slag-metal experiments was first carried out to determine the reaction time needed for the system to reach equilibrium. A slag of composition $30 \% \mathrm{Al}_{2} \mathrm{O}_{3}-40 \% \mathrm{CaO}-10 \%$ $\mathrm{MgO}-20 \% \mathrm{SiO}_{2}$ (by weight) was equilibrated with $\mathrm{Si}$ alloy at $1500{ }^{\circ} \mathrm{C}$ at six reaction times up to 6 hours. Analysis of the Si at the completion of each run showed that the concentration of phosphorus and boron became steady after 2 hours. Similarly, the $\mathrm{SiO}_{2}$ content of the slag, which can possibly increase due to the oxidation of $\mathrm{Si}$, did not show appreciable systematic variation after this time. This is shown in Fig. 2. On the basis of this, a reaction time of 2 hours was used in subsequent experiments.

\subsection{Analysis}

Silicon alloys were digested in a mixture of concentrated nitric and hydrofluoric acids (trace-element grade, Celadon) in PTFE beakers at about $80{ }^{\circ} \mathrm{C}$ and the resulting solutions analysed by ICP-OES. Slags were fused with sodium hydroxide (99.99\%, Sigma-Aldrich) in an Inconel $601^{1}$ crucible at around $450{ }^{\circ} \mathrm{C}$ then dissolved in diluted nitric acid prior to ICP analysis for boron and iron. The slags were analysed by XRF for all other elements reported.

\section{Results}

From the analytical results, distribution coefficients and removal efficiencies were calculated. The distribution coefficient is the simple ratio of concentration of impurity $\mathrm{M}$ (in $\mathrm{wt} \%$ ) in the slag phase (M) to that in the metal phase [M].

$L_{\mathrm{M}}=(\mathrm{M}) /[\mathrm{M}]$

Because of the possibility of oxidized silicon entering the slag (as in Fig. 2 above) and the saturation of the slag by the crucible material over the course of the experiments, the distribution data are presented and discussed below in terms of the final slag composition as determined by chemical analysis. Published phase diagrams of the $\mathrm{Al}_{2} \mathrm{O}_{3}-\mathrm{CaO}-\mathrm{MgO}-\mathrm{SiO}_{2}$ system [13] show that the mullite phase is stabilized at high silica contents, but in the present work it is expected that the alumina content is always low enough such that this phase does not form. The target and final slag compositions are given in Table II.

\subsection{Varying $\mathrm{CaO}: \mathrm{SiO}_{2}$}

The effect of slag basicity on the removal of impurities from silicon was investigated by varying the $\mathrm{CaO}: \mathrm{SiO}_{2}$ ratio of the $\mathrm{Al}_{2} \mathrm{O}_{3}-\mathrm{CaO}-\mathrm{MgO}-\mathrm{SiO}_{2}$ slag with $\mathrm{Al}_{2} \mathrm{O}_{3}$ and $\mathrm{MgO}$ fixed at 35 and $3 \mathrm{wt} \%$ respectively. All experiments were conducted in alumina crucibles. Values of $L_{\mathrm{M}}$ for the varying $\mathrm{CaO}: \mathrm{SiO}_{2}$ system are shown in Fig. 3. For boron, the changing dependence on basicity is clearly highlighted by the local maximum observed at a $\mathrm{CaO}: \mathrm{SiO}_{2}$ ratio of about 0.6. The actual values of $L_{\mathrm{B}}$ are greater than unity for all but one composition, indicating boron partitions preferentially to the slag phase. However the maximum reached is only about 1.6, indicating that this preference is only slight. For phosphorus, the distribution coefficient increases steadily over the entire range of basicity studied. This indicates that the influences on

\footnotetext{
${ }^{1}$ Inconel is a registered trademark of Special Metals Corporation, New Hartford, New York, USA.
} 
phosphorus are different to those responsible for removal of boron. The actual values of $L_{\mathrm{P}}$ are all less than unity, indicating a preference to remain in the metal phase.

Values for iron and potassium are subject to significant scatter, most likely due to their low concentrations in the starting alloy. Generally, values of $L_{\mathrm{Fe}}$ are of the order of 0.1 , indicating that $\mathrm{Fe}$ is retained in the metal, although do become just greater than unity in the most basic slags. For potassium, values are mostly in the range $1<L_{\mathrm{K}}<2$, indicating a slight preference for the slag phase.

\subsection{Varying $\mathrm{SiO}_{2}: \mathrm{Al}_{2} \mathrm{O}_{3}$}

The effect of the oxygen potential ( $p_{\mathrm{O}_{2}}$ ) of the slag on the removal of impurities from silicon was investigated at constant $(B)$ by varying the $\mathrm{SiO}_{2}: \mathrm{Al}_{2} \mathrm{O}_{3}$ ratio of the $\mathrm{Al}_{2} \mathrm{O}_{3}-\mathrm{CaO}-\mathrm{MgO}-$ $\mathrm{SiO}_{2}$ slag with $\mathrm{CaO}$ and $\mathrm{MgO}$ fixed at 42 and $10 \mathrm{wt} \%$ respectively. All experiments were conducted in magnesia crucibles. Distribution coefficients for impurity elements in these experiments are shown in Fig. 4. In this case, the distribution coefficient of boron shows a slight increasing trend with increasing $\mathrm{SiO}_{2}: \mathrm{Al}_{2} \mathrm{O}_{3}$ ratio. Values all lie in the range $1<L_{\mathrm{B}}<2$ so again, boron only slightly favours the slag phase. The distribution coefficient of phosphorus shows a change in dependence with a continued increase in $p_{\mathrm{O}_{2}}$, in that above an $\mathrm{SiO}_{2}: \mathrm{Al}_{2} \mathrm{O}_{3}$ ratio of 2 , $L_{\mathrm{P}}$ shows a sharp increase. This is despite the slag being expected to become less basic over this interval, as the quantitative measure of basicity, the optical basicity $(\Lambda)$, is higher for $\mathrm{Al}_{2} \mathrm{O}_{3}$ than for $\mathrm{SiO}_{2}$ [13]. The highest $L_{\mathrm{B}}$ and $L_{\mathrm{P}}$ in the present study were recorded in the slag with the highest $\mathrm{SiO}_{2}: \mathrm{Al}_{2} \mathrm{O}_{3}$ ratio, which suggests that the $p_{\mathrm{O}_{2}}$, and not basicity, may by the major influencing factor on the removal of these impurities. Distribution coefficients for iron and phosphorus were very similar to those measured in the varying $\mathrm{CaO}: \mathrm{SiO}_{2}$ system and are again subject to scatter. This suggests that these metallic impurities are not particularly responsive to changes in slag chemistry.

\subsection{Varying $\mathrm{BaO}: \mathrm{SiO}_{2}$}

The effect of slag basicity on the removal of impurities from silicon was further investigated by varying the $\mathrm{BaO}: \mathrm{SiO}_{2}$ ratio of the $\mathrm{Al}_{2} \mathrm{O}_{3}-\mathrm{BaO}--\mathrm{SiO}_{2}$ slag with $\mathrm{Al}_{2} \mathrm{O}_{3}$ fixed at 20 $\mathrm{wt} \%$. All experiments were conducted in alumina crucibles. Distribution coefficients for impurity elements in these experiments are shown in Fig. 5. Values for boron follow a similar trend as for the varying $\mathrm{CaO}: \mathrm{SiO}_{2}$ slags in that they increase with increasing basicity, but in this case are all less than unity. The distribution coefficient of phosphorus, on the other hand, was seen to be independent of basicity in this system. This is a somewhat unexpected result, as barium is expected to be the most basic flux used in this study, so should be more efficient at taking up acidic impurity elements. Distribution coefficients of $\mathrm{Ca}$ and $\mathrm{Mg}$ are interesting in that they appear to follow opposite trends, despite being chemically very similar. Values for Mg decrease with increasing $\mathrm{BaO}: \mathrm{SiO}_{2}$, while those for $\mathrm{Ca}$ increase over the same range. Values for both are always greater than unity, with those for $\mathrm{Mg}$ about an order of magnitude higher than for $\mathrm{Ca}$. Values for $\mathrm{K}$ very closely follow the same trend as $\mathrm{Ca}$. Distribution coefficients for iron are at similar levels as found previously and again do not follow any particular trend against basicity. 


\section{Discussion}

The reaction for boron entering the slag by oxidation with silica as the oxidising agent can be represented by the ionic reaction

$[\mathrm{B}]+3 / 2 \mathrm{O}^{2-}+3 / 4 \mathrm{O}_{2} \rightleftharpoons\left(\mathrm{BO}_{3}{ }^{3-}\right)$

Similarly, phosphorus enters the slag by the reaction

$[\mathrm{P}]+3 / 2 \mathrm{O}^{2-}+5 / 4 \mathrm{O}_{2} \rightleftharpoons\left(\mathrm{PO}_{4}{ }^{3-}\right)$

In each case, oxygen ions are provided by basic oxides such as lime

$(\mathrm{CaO}) \rightleftharpoons \mathrm{Ca}^{2+}+\mathrm{O}^{2-}$

and the oxygen partial pressure is that resulting from the equilibrium between $\mathrm{Si}$ and $\mathrm{SiO}_{2}$

$\left(\mathrm{SiO}_{2}\right) \rightleftharpoons \mathrm{Si}+\mathrm{O}_{2}$

To estimate the $p_{\mathrm{O}_{2}}$, the activities of $\mathrm{Si}\left(a_{\mathrm{Si}}\right)$ and $\mathrm{SiO}_{2}\left(a_{\mathrm{SiO}_{2}}\right)$ were first estimated using the FactSage ${ }^{2}$ thermodynamic package for the $\mathrm{Al}_{2} \mathrm{O}_{3}-\mathrm{CaO}-\mathrm{MgO}-\mathrm{SiO}_{2}$ slags and the correlation of Meraikib [14] for the barium-containing slags (for $a_{\mathrm{SiO}_{2}}$ only). A value for the equilibrium constant $(K)$ of Eq. (5) above of $3.95 \times 10^{-18}$ [15] was also used. It should be noted, however, that the $p_{\mathrm{O}_{2}}$ may change slowly in response to the compositional changes of the slag, such that full chemical equilibrium may not be attained in the reaction time of 2 hours. In the varying $\mathrm{SiO}_{2}: \mathrm{Al}_{2} \mathrm{O}_{3}$ system, the $p_{\mathrm{O}_{2}}$ was lower, in the range $4 \times 10^{-20}$ to $9 \times 10^{-20} \mathrm{~atm}$. Based on previous studies in a similar system [16], phosphorus is expected to exist in the slag as the phosphide $\left(\mathrm{P}^{3-}\right)$ under these conditions. Under these conditions, phosphorus is expected to exist solely as a reduced phosphide species. However, the observed increase in $L_{\mathrm{P}}$ and $L_{\mathrm{B}}$ with varying $\mathrm{SiO}_{2}: \mathrm{Al}_{2} \mathrm{O}_{3}$ ratio in this system corresponds with increasing $p_{\mathrm{O}_{2}}$. This suggests that these elements exist in the slag as an oxidized species under the conditions employed in the present work. For the varying $\mathrm{CaO}: \mathrm{SiO}_{2}$ and varying $\mathrm{BaO}: \mathrm{SiO}_{2}$ systems, the $p_{\mathrm{O}_{2}}$ was always in the range $1 \times 10^{-19}$ to $4 \times 10^{-18} \mathrm{~atm}$. In this range, phosphorus was found to exist as both the phosphide and phosphate $\left(\mathrm{PO}_{4}{ }^{3-}\right)$ in a previous study [16]. But as these conditions are more oxidizing than those in the varying $\mathrm{SiO}_{2}: \mathrm{Al}_{2} \mathrm{O}_{3}$ system, it is expected that boron and phosphorus exist solely as oxidized species in these systems. This was supported by further calculations using FactSage that showed the phosphate as the stable form of phosphorus in the slag in all experiments.

Thus, the removal and hence distribution of these elements will be a function of both slag basicity and $a_{\mathrm{SiO}_{2}}$. However, since slag network modifiers such as $\mathrm{CaO}$ and $\mathrm{MgO}$ have a strong affinity for silica, an excess amount of these fluxes will give a highly basic slag at the expense of

\footnotetext{
${ }^{2}$ FactSage is a registered trademark of GTT Technologies, Herzogenrath, Germany.
} 
lowering $a_{\mathrm{SiO}_{2}}$. Increasing the basicity too far may then have the effect of impeding the removal of these elements as the $p_{\mathrm{O}_{2}}$ is in turn reduced.

This can account for the observed trend in $L_{\mathrm{B}}$ values in the varying $\mathrm{CaO}: \mathrm{SiO}_{2}$ system. Boron, having a relatively weakly acidic oxide, is likely to only have weak affinity for a basic slag. Therefore, it is apparent that there is a point where the $p_{\mathrm{O}_{2}}$ takes over from basicity as the dominant influence on boron removal. Since basicity no longer has a significant effect on the weakly acidic $\mathrm{BO}_{3}{ }^{3-}$ beyond this point, the continuing decrease in $a_{\mathrm{SiO}_{2}}$ will bring about the observed decrease in $L_{\mathrm{B}}$. Such a trend has also been observed in $\mathrm{CaO}-\mathrm{CaF}_{2}-\mathrm{SiO}_{2}$ slags at 1500 ${ }^{\circ} \mathrm{C}$ [17], and in $\mathrm{Al}_{2} \mathrm{O}_{3}-\mathrm{CaO}-\mathrm{SiO}_{2}$ slag at $1600{ }^{\circ} \mathrm{C}$ [18]. The actual maximum value of $L_{\mathrm{B}}=1.6$ in the varying $\mathrm{CaO}: \mathrm{SiO}_{2}$ system of this study is slightly higher than the 1.1 recorded for the $\mathrm{Al}_{2} \mathrm{O}_{3}$ $\mathrm{CaO}-\mathrm{SiO}_{2}$ slag by Fujiwara et al. [18]. This may be due to the presence of $\mathrm{MgO}$ in the slag in the present work, which is a reasonably strong basic oxide, so is expected to contribute significantly to the removal of boron. The $L_{\mathrm{B}}$ of 1.6 is also very close to the value of 1.7 recorded in the $\mathrm{CaO}-\mathrm{CaF}_{2}-\mathrm{SiO}_{2}$ slags by Suzuki et al. [17], indicating that $\mathrm{CaF}_{2}$ as a flux can also contribute to slag basicity and removal of impurities. In both of these magnesia-free systems, the maximum $L_{\mathrm{B}}$ was recorded at a $\mathrm{CaO}: \mathrm{SiO}_{2}$ ratio of about 1.9 , which corresponds to the calcium orthosilicate $\left(2 \mathrm{CaO} . \mathrm{SiO}_{2}\right)$ composition. For the $\mathrm{Al}_{2} \mathrm{O}_{3}-\mathrm{CaO}-\mathrm{MgO}-\mathrm{SiO}_{2}$ slag in the present work, the maximum $L_{\mathrm{B}}$ was measured at a $\mathrm{CaO}: \mathrm{SiO}_{2}$ ratio of about 0.7. Lynch [11] states that the orthosilicate composition will exist at lower ratios when $\mathrm{MgO}$ is present in the slag, which may account for this discrepancy.

Phosphorus, having a stronger acidic oxide than boron, should be more susceptible to changes in the slag basicity. As the values of $L_{\mathrm{P}}$ increase over the entire range of $\mathrm{CaO}: \mathrm{SiO}_{2}$ ratios studied, it is apparent that basicity always has a stronger influence than $p_{\mathrm{O}_{2}}$ on the removal behaviour of phosphorus in this case. However, the overall influence is sufficiently weak that values of $L_{\mathrm{P}}$ are always less than unity, indicating a preference for the metal phase. An increase in $L_{\mathrm{P}}$ through a local maximum value was observed with increasing lime content of slag for the $\mathrm{Al}_{2} \mathrm{O}_{3}-\mathrm{CaO}-\mathrm{SiO}_{2}$ system at $1600{ }^{\circ} \mathrm{C}$ [19], but was not observed in the present work.

While basicity in terms of $(B)$ was constant in the varying $\mathrm{SiO}_{2}: \mathrm{Al}_{2} \mathrm{O}_{3}$ system, the increase in the $\mathrm{SiO}_{2}: \mathrm{Al}_{2} \mathrm{O}_{3}$ ratio of the slag leads to an increase in $a_{\mathrm{SiO}_{2}}$ and therefore $p_{\mathrm{O}_{2}}$. The increasing trend observed in $L_{\mathrm{B}}$ and $L_{\mathrm{P}}$ over the same interval confirms that the $p_{\mathrm{O}_{2}}$ does have a strong influence on the removal of these elements when basicity is constant. However, the effect of $p_{\mathrm{O}_{2}}$ on phosphorus is much stronger compared to that for boron, as is evident from the sharp increase in the $L_{\mathrm{P}}$ data. Also, the effect of basicity on phosphorus must still be sufficiently strong such that $L_{\mathrm{P}}$ does not decrease where highly basic slags reduce the $p_{\mathrm{O}_{2}}$, as was apparent in the varying $\mathrm{CaO}: \mathrm{SiO}_{2}$ system.

Distribution coefficients for boron and phosphorus in the varying $\mathrm{BaO}: \mathrm{SiO}_{2}$ system follow a similar trend to those observed in the varying $\mathrm{CaO}: \mathrm{SiO}_{2}$ system. However, the values measured are lower, and always favour the metal phase. Also, $L_{\mathrm{P}}$ appears to be independent of the slag basicity. This is an unexpected result, as $\mathrm{BaO}$ was the most basic flux used and was expected to have a stronger influence on partitioning than lime or magnesia. The reason that $L_{\mathrm{M}}$ for these slags behave as observed is that $\mathrm{BaO}$ has a much higher molecular weight than $\mathrm{CaO}$ or $\mathrm{MgO}$, such that at the concentrations in these slags, the number of moles present in the slag is comparatively lower. As a result, the overall basicity of the slags in terms of $\Lambda$ in this system 
were lower than the others studied in this work. Values for the varying $\mathrm{BaO}: \mathrm{SiO}_{2}$ system are in the range $0.55<\Lambda<0.61$ compared to $0.58<\Lambda<0.66$ for the varying $\mathrm{CaO}: \mathrm{SiO}_{2}$ system.

Furthermore, due to the action of $\mathrm{BaO}$ as a strong base, the decreasing $a_{\mathrm{SiO}_{2}}$ effect will be greater, resulting in slags with lower oxygen potential. Thus, $L_{M}$ will be smaller in both regions of influence.

\section{Impurity Removal efficiency}

The percent removal of born and phosphorus from silicon was calculated from the difference between the initial and final mass of the impurity in the metal phase as a ratio to the initial mass in the Si alloy as determined from the chemical analyses and was reported elsewhere [20]. Removal efficiencies $(R)$ and $L_{\mathrm{M}}$ are related through the expression shown as Eq. (6), assuming negligible impurity $(\mathrm{M})$ content of the starting slag

$$
L_{\mathrm{M}}=\left(\frac{R}{1-R}\right) \frac{m_{S i}}{m_{\text {slag }}}
$$

where $m_{\mathrm{Si}}$ and $m_{\text {slag }}$ are the mass of silicon and slag respectively and. When $R /(1-R)$ is then plotted against $L_{\mathrm{M}}\left(m_{\text {slag }} / m_{\mathrm{Si}}\right)$ as shown in Fig. 6, a straight line with a slope of 1 should be obtained. Thus, one parameter can be used to predict the other.

Rearranging Eq. (6) to the form of Eq. (7) shows how the absolute removal is determined by the distribution coefficient (which is characteristic of the particular slag) and the ratio of masses of silicon and slag.

$$
R=\frac{L_{\mathrm{M}}}{L_{\mathrm{M}}+\frac{m_{S i}}{m_{\text {slag }}}}
$$

Thus it is apparent that an excess of slag will give higher removals, but as in any pyrometallurgical process, it is not desirable to handle large slag volumes from a cost and practicality standpoint. For a typical MG-Si containing $15 \mathrm{ppm} \mathrm{B}$ and $30 \mathrm{ppm} \mathrm{P}$, the amount of slag required for it to be refined to SoG-Si purity can be estimated. For final levels of $1.5 \mathrm{ppm} \mathrm{B}$ and 1 ppm P, $R$ need to be $90 \%$ and $97 \%$ respectively. For treatment with the slag that resulted in the highest $L_{\mathrm{M}}{ }^{3}$ this translates to a slag mass roughly 5.5 times that of silicon for treatment of boron and 3.3 times that of silicon for treatment of phosphorus. Obviously where both these elements are present, the larger slag amount will be needed to remove both to SoG-Si levels. The amount of slag required can be lowered by operating where $L_{\mathrm{M}}$ will be higher, but it follows that the composition of the slag must only be adjusted such that the melting point is not so high as to have an excessively large energy requirement to keep a large volume of slag molten. This may be achieved by adding small amounts of other fluxes such as $\mathrm{CaF}_{2}$ to the melt.

\section{Summary and Conclusions}

${ }^{3} 9 \% \mathrm{Al}_{2} \mathrm{O}_{3}-24 \% \mathrm{CaO}-33 \% \mathrm{MgO}-34 \% \mathrm{SiO}_{2} ; L_{\mathrm{B}}=1.8, L_{\mathrm{P}}=8.8$ 
The distribution of impurity elements present in MG-Si between slag and silicon metal phases was examined using $\mathrm{Al}_{2} \mathrm{O}_{3}-\mathrm{CaO}-\mathrm{MgO}-\mathrm{SiO}_{2}$ and $\mathrm{Al}_{2} \mathrm{O}_{3}-\mathrm{BaO}_{-} \mathrm{SiO}_{2}$ slags at $1500{ }^{\circ} \mathrm{C}$ with particular focus on boron and phosphorus. Where the basicity of the barium-free slag was increased by increasing the $\mathrm{CaO}: \mathrm{SiO}_{2}$ ratio, distribution coefficients for phosphorus increased slightly, while those for boron increased through a local maximum. This indicated that the oxygen potential of the slag, which is dependent on the activity of the slag components, also has a strong influence on impurity partitioning. This was confirmed through increasing the $p_{\mathrm{O}_{2}}$ of the slag by varying the $\mathrm{SiO}_{2}: \mathrm{Al}_{2} \mathrm{O}_{3}$ ratio at constant basicity, which leads to an increase in distribution coefficient for both boron and phosphorus. The low values and weak dependence of the distribution coefficients in the barium-containing slags is attributed to the relatively low optical basicity and $p_{\mathrm{O}_{2}}$ for the compositions studied. It is suggested that a slag with strongly basic and oxidising characteristics would be most useful for extracting boron and phosphorus from silicon. However, it may be difficult to remove both of these elements to the required levels for SoG-Si effectively with a single slagging step due to the different magnitude of the distribution coefficients and different responses to changing slag chemistry. A multi-step programme of refining is therefore likely to be necessary to achieve the required level of silicon purity.

\section{Acknowledgements}

Funding for this work was provided by NSERC and ARISE Technologies Corporation.

\section{References}

[1] E.A. Alsema, M. J. de Wild-Scholten, Environmental life cycle assessment of advanced silicon solar cell technologies, in: 19th European Photovoltaic Solar Energy Conference, WIPRenewable Energies, Munich, 2004.

[2] L. Gagnon, C. Bélangery, Y. Uchiyama, Life-cycle assessment of electricity generation options: The status of research in year 2001, Energy Policy 30 (14) (2002) 1267-1278.

[3] http://www.solarbuzz.com/SolarPrices.htm last accessed 8th March 2010

[4] K. Mimura, M. Kishida, M. Isshiki, S.G. Kim, W.T. Kim, T. Suzuki, Plasma-arc zone refining of silicon, in: Second International Conference on Processing Materials for Properties; TMS, Warrendale, PA, 2000, pp. 1059-1064.

[5] S. Esfahani, M. Barati, Z. Yin, A novel purification method for production of solar grade silicon, in: Materials Challenges in Alternative and Renewable Energy 2010 Conference, American Ceramic Society, Westerville, Ohio, 2010, in press.

[6] J.C.S. Pires, J. Otubo, A.F.B. Braga, P.R. Mei, The purification of metallurgical grade silicon by electron beam melting, J Mat. Proc. Tech. 169 (1) (2005) 16-20.

[7] M. Tanahashi, M. Sano, C. Yamauchi, K. Takeda, Oxidation removal behavior of boron and local nonequilibrium reaction field in purification process of molten silicon by the flux injection 
technique, in: F. Kongoli and R.G. Reddy (Eds.), Sohn International Symposium, Volume 1 Thermo and physicochemical principles, TMS, Warrendale, PA, 2006, pp. 173-186.

[8] M. Tanahashi, H. Nakahigashi, K. Takeda and C. Yamauchi, Removal of boron from metallurgical-grade silicon by applying CaO-based flux treatment, in: F. Kongoli et al. (Eds.), Yazawa International Symposium, Volume 1: Materials processing fundamentals and new technologies, TMS, Warrendale, PA, 2003, pp. 613-624.

[9] L. Teixiera, and K. Morita, Thermodynamic properties and structural assessment of boron oxide in $\mathrm{CaO}-\mathrm{SiO}_{2}$ and $\mathrm{CaO}-\mathrm{SiO}_{2}-\mathrm{CaF}_{2}$ slags for silicon refining, in: Molten 2009 Conference, 2009, pp. 319-326.

[10] T. Weiss, K. Schwerdtfeger, Chemical equilibria between silicon and slag melts, Metall. Trans. B, 25B (4) (1994) 497-504.

[11] D. Lynch, Winning the global race for solar silicon, JOM, 61 (11) (2009) 41-48.

[12] K. Morita, T. Miki, Thermodynamics of solar-grade-silicon refining, Intermetallics, 11 (1112) (2003) 1111-1117.

[13] Slag Atlas $2^{\text {nd }}$ Edition, Verlag Stahleisen GmbH, Düsseldorf, 1995.

[14] M. Meraikib, Ironmaking Steelmaking, 33 (2) (2006) 120-128.

[15] O. Kubaschewski, E.L. Evans, C.B. Alcock, Metallurgical Thermochemistry, Pergamom Press, New York, 1967

[16] H. Momokawa, N. Sano, The effect of oxygen potential on phosphorus in the $\mathrm{CaO}-\mathrm{Al}_{2} \mathrm{O}_{3}$ system, Metall. Trans. B, 13B (4) (1982) 643-644.

[17] K. Suzuki, N. Sano, Thermodynamics for removal of boron from metallurgical silicon by flux treatment, in: A. Luqúe et al (Eds.), 10 ${ }^{\text {th }}$ E.C. Photovoltaic Solar Energy Conference, Kluwer, Dordrecht, 1991, pp. 273-275.

[18] H. Fujiwara, L.J. Yuan, K. Miyata. E. Ichise, R. Otsuka, Distribution equilibria of the metallic elements and boron between $\mathrm{Si}$ based liquid alloys and $\mathrm{CaO}-\mathrm{Al}_{2} \mathrm{O}_{3}-\mathrm{SiO}_{2}$ fluxes, J. JIM, 60 (1) (1996) 65-71.

[19] H. Fujiwara, L.J. Yuan, K. Takeuchi, E. Ichise, Reducing Removal of Phosphorous from Calcium Containing Silicon Alloys, Trans. JIM, 37 (4) (1996) 923-926.

[20] M.D. Johnston and M. Barati, Metallurgical refining of silicon for solar applications by slagging of impurity elements, in: Materials Challenges in Alternative and Renewable Energy 2010 Conference, American Ceramic Society, Westerville, Ohio, 2010, in press. 
Table 1. Chemical analysis of silicon master alloys used in equilibration experiments. All values are in wt pct.

\begin{tabular}{|c|c|c|c|c|c|c|c|}
\hline Alloy & $\mathrm{Al}$ & $\mathrm{Ca}$ & $\mathrm{Mg}$ & $\mathrm{B}$ & $\mathrm{P}$ & $\mathrm{K}$ & $\mathrm{Fe}$ \\
\cline { 1 - 6 } 1 & 0.208 & 0.012 & 0.238 & 0.190 & 0.038 & 0.012 & 0.395 \\
\cline { 1 - 3 } & 0.095 & 0.055 & 0.114 & 0.261 & 0.063 & 0.009 & 0.270 \\
\hline
\end{tabular}

Table 2. Composition of slags before and after equilibrium experiments.

\begin{tabular}{|c|c|c|c|c|c|c|c|c|c|c|}
\hline \multirow{2}{*}{ Test ID } & \multicolumn{5}{|c|}{ Target (wt\%) } & \multicolumn{5}{|c|}{ Final (wt\%) } \\
\hline & $\mathrm{Al}_{2} \mathrm{O}_{3}$ & $\mathrm{BaO}$ & $\mathrm{CaO}$ & $\mathrm{MgO}$ & $\mathrm{SiO}_{2}$ & $\mathrm{Al}_{2} \mathrm{O}_{3}$ & $\mathrm{BaO}$ & $\mathrm{CaO}$ & $\mathrm{MgO}$ & $\mathrm{SiO}_{2}$ \\
\hline \multicolumn{11}{|c|}{ Alumina crucibles } \\
\hline CS031 & 35 & - & 14.5 & 3 & 47.5 & 40.8 & - & 12.1 & 3.81 & 44.5 \\
\hline CS044 & 35 & - & 19 & 3 & 43 & 41.1 & - & 14.5 & 4.16 & 42.1 \\
\hline CS061 & 35 & - & 23.5 & 3 & 38.5 & 39.8 & - & 16.5 & 3.20 & 41.6 \\
\hline CS082 & 35 & - & 28 & 3 & 34 & 39.1 & - & 17.6 & 3.39 & 41.3 \\
\hline CS107 & 35 & - & 32 & 3 & 30 & 38.1 & - & 18.6 & 2.91 & 41.6 \\
\hline CS288 & 35 & - & 46 & 3 & 16 & 51.5 & - & 22.7 & 2.11 & 24.4 \\
\hline CS377 & 35 & - & 49 & 3 & 13 & 53.3 & - & 24.8 & 2.09 & 20.4 \\
\hline CS520 & 35 & - & 52 & 3 & 10 & 52.7 & - & 27.7 & 2.86 & 18.0 \\
\hline CS786 & 35 & - & 55 & 3 & 7 & 52.9 & - & 28.8 & 2.67 & 16.6 \\
\hline BS045 & 20 & 25 & - & - & 55 & 25.6 & 22.6 & - & - & 51.7 \\
\hline BS060 & 20 & 30 & - & - & 50 & 27.8 & 25.7 & - & - & 46.5 \\
\hline BS077 & 20 & 35 & - & - & 45 & 28.0 & 31.8 & - & - & 40.1 \\
\hline BS100 & 20 & 40 & - & - & 40 & 32.0 & 33.3 & - & - & 34.6 \\
\hline BS128 & 20 & 45 & - & - & 35 & 30.7 & 38.7 & - & - & 30.6 \\
\hline \multicolumn{11}{|c|}{ Magnesia crucibles } \\
\hline SA007 & 45 & - & 42 & 10 & 3 & 27.3 & - & 30.3 & 19.8 & 17.4 \\
\hline SA020 & 40 & - & 42 & 10 & 8 & 23.5 & - & 26.0 & 25.9 & 23.3 \\
\hline SA037 & 35 & - & 42 & 10 & 13 & 21.4 & - & 29.7 & 20.7 & 24.7 \\
\hline SA060 & 30 & - & 42 & 10 & 18 & 16.8 & - & 27.8 & 25.2 & 27.2 \\
\hline SA092 & 25 & - & 42 & 10 & 23 & 14.2 & - & 27.4 & 27.5 & 28.8 \\
\hline SA140 & 20 & - & 42 & 10 & 28 & 10.5 & - & 25.7 & 30.7 & 31.4 \\
\hline SA220 & 15 & - & 42 & 10 & 33 & 8.87 & - & 24.6 & 32.9 & 33.8 \\
\hline
\end{tabular}




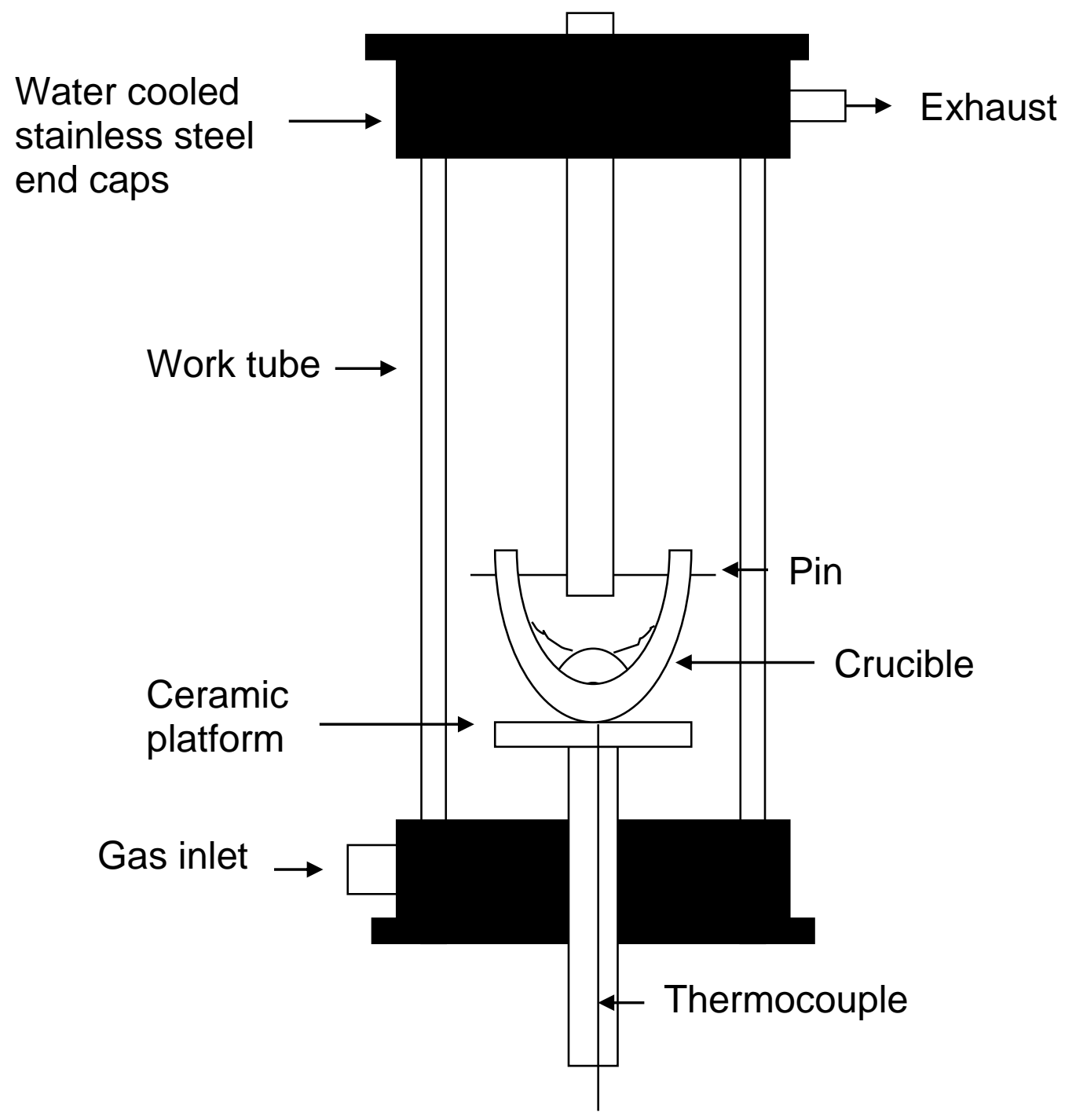

Figure 1. Schematic diagram of the furnace setup 


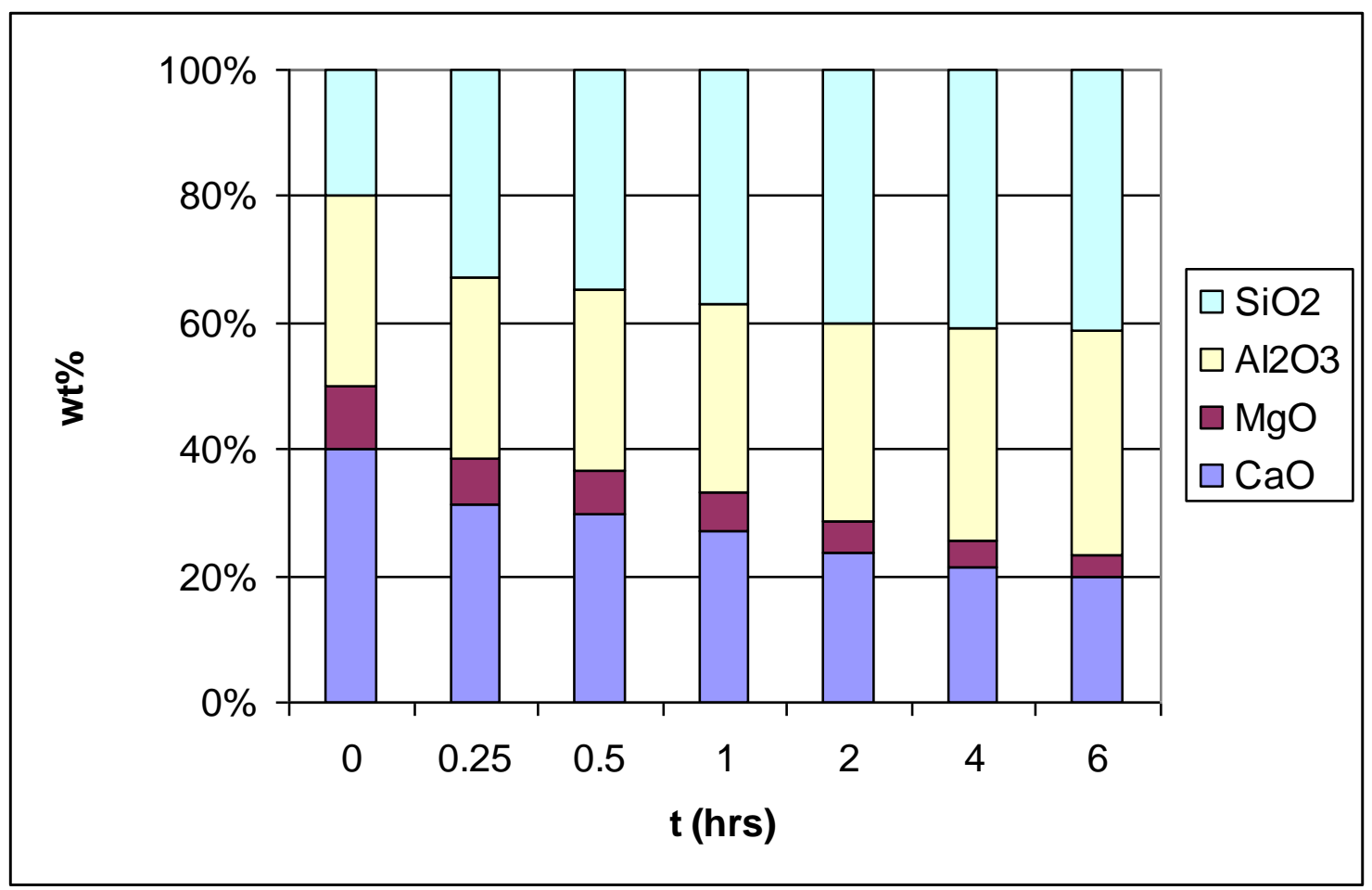

Figure 2. Normalised slag composition. Major oxides comprise $\sim 99.7 \%$ of total assay 


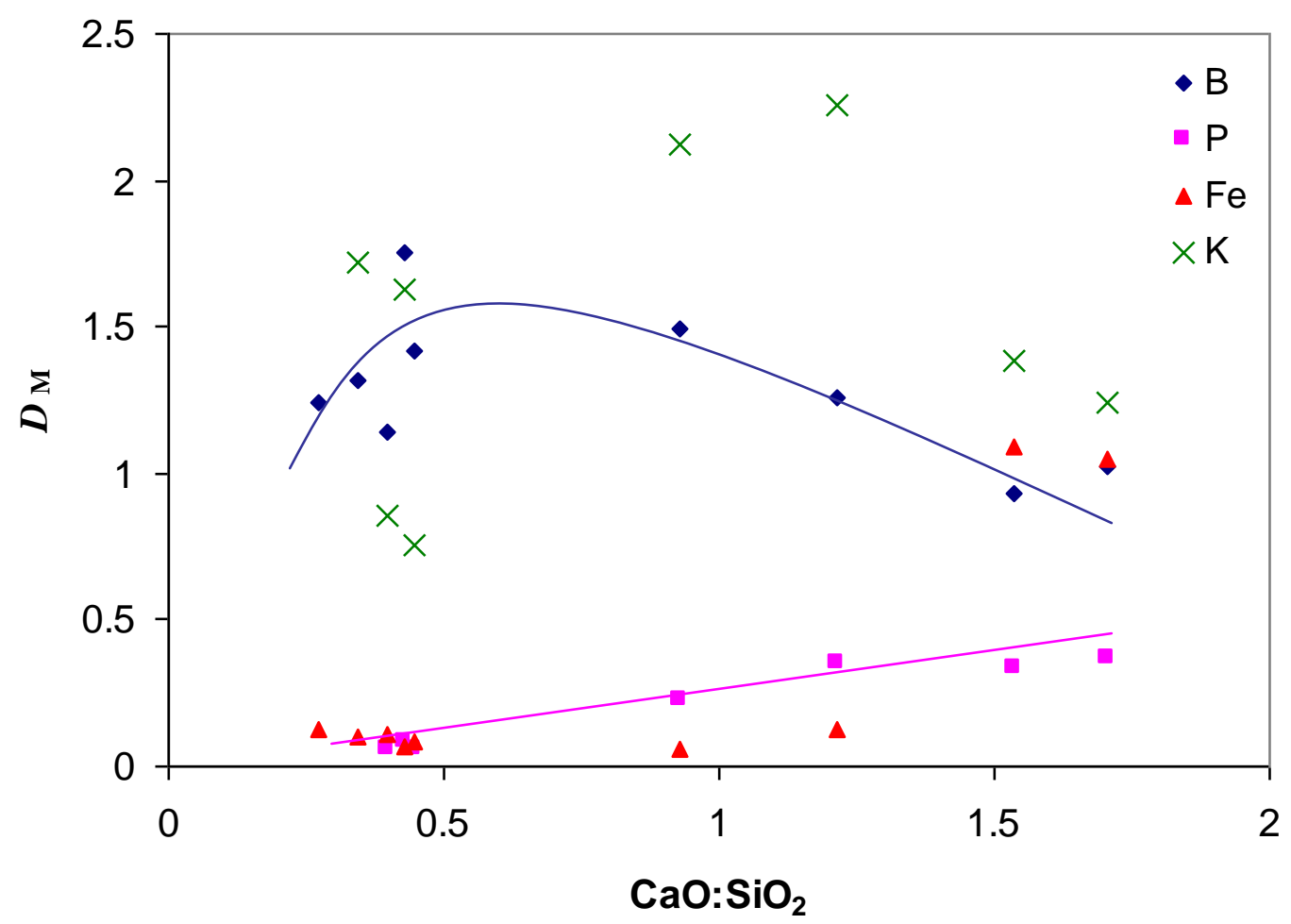

Figure 3. Distribution coefficients for impurities between slag and $\mathrm{Si}$ in varying $\mathrm{CaO}: \mathrm{SiO}_{2}$ $\left(35 \% \mathrm{Al}_{2} \mathrm{O}_{3}-\mathrm{CaO}-3 \% \mathrm{MgO}-\mathrm{SiO}_{2}\right)$ slags 


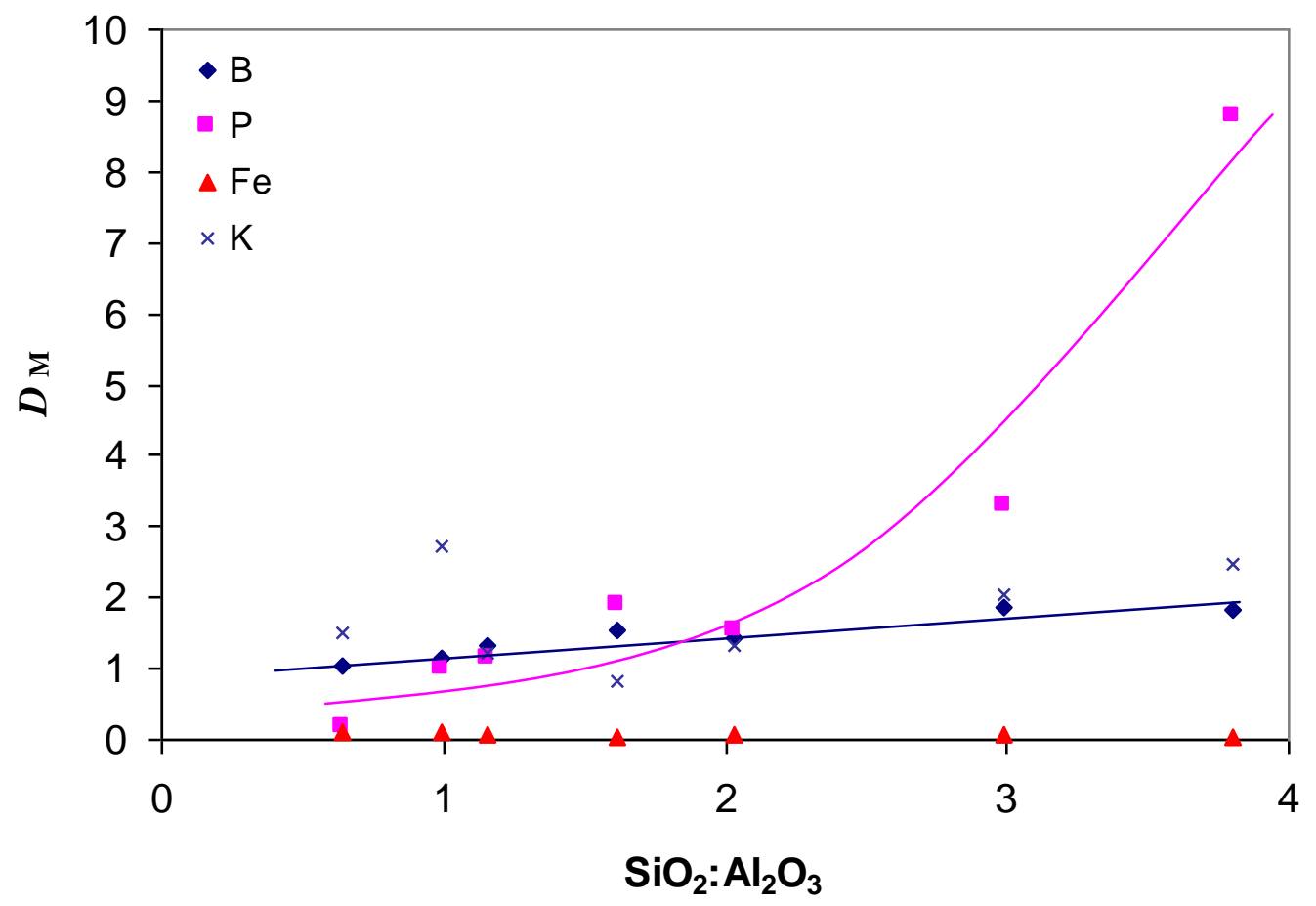

Figure 4. Distribution coefficients for impurities between slag and $\mathrm{Si}$ in varying $\mathrm{SiO}_{2}: \mathrm{Al}_{2} \mathrm{O}_{3}$ $\left(\mathrm{Al}_{2} \mathrm{O}_{3}-42 \% \mathrm{CaO}-10 \% \mathrm{MgO}-\mathrm{SiO}_{2}\right)$ slags

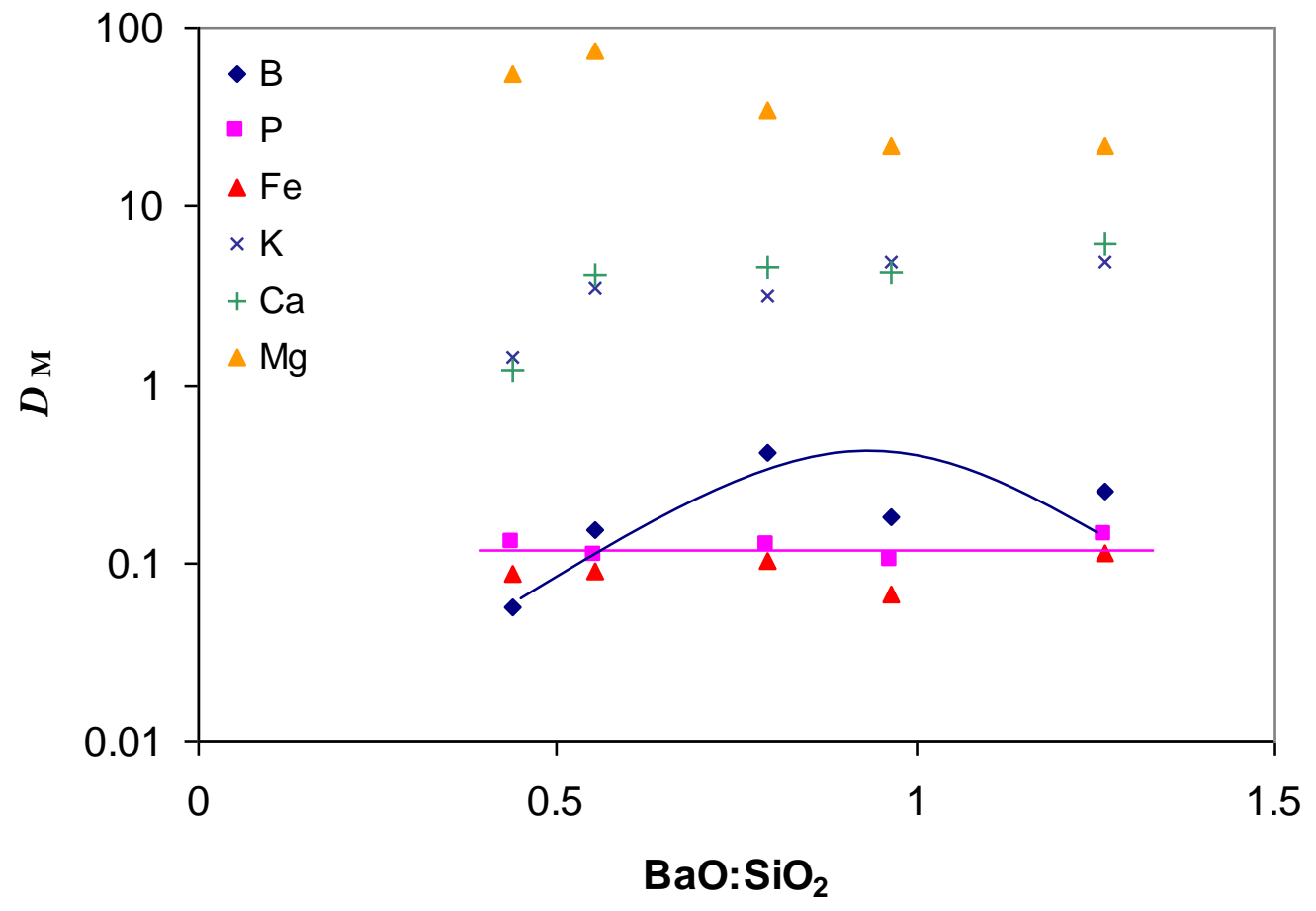

Figure 5. Distribution coefficients for impurities between slag and $\mathrm{Si}$ in varying $\mathrm{BaO}: \mathrm{SiO}_{2}$ $\left(20 \%-\mathrm{Al}_{2} \mathrm{O}_{3}-\mathrm{BaO}-\mathrm{SiO}_{2}\right)$ slags 